\title{
Angiotensin II receptor type 1 blockers suppress the cell proliferation effects of angiotensin II in breast cancer cells by inhibiting AT1R signaling
}

\author{
NING DU ${ }^{1}$, JIANG FENG $^{2}$, LI-JUAN HU ${ }^{1}$, XIN SUN $^{1}$, HAI-BING SUN ${ }^{1}$, \\ YANG ZHAO $^{1}$, YI-PING YANG ${ }^{3}$ and HONG REN ${ }^{1}$ \\ ${ }^{1}$ Department of Oncosurgery, First Affiliated Hospital, Xi'an Jiaotong University, Xi'an, Shaanxi 710061; \\ ${ }^{2}$ Department of General Surgery, Second Affiliated Hospital, Yan'an University, Yulin, Shaanxi 719000; \\ ${ }^{3}$ Department of Radiotherapy, Shaanxi Province Tumor Hospital, Xi'an, Shaanxi 710061, P.R. China
}

Received November 22, 2011; Accepted February 7, 2012

DOI: $10.3892 / o r .2012 .1720$

\begin{abstract}
Chronic stress and a high-fat diet are well-documented risk factors associated with the renin-angiotensin system in the development of breast cancer. The angiotensin II type 1 receptor (AT1R) is a novel component of the reninangiotensin system. Several recent studies have focused on the function of AT1R in cell proliferation during cancer development. Thus, we hypothesized that angiotensin II (Ang II) can promote proliferation of breast cancer via activated AT1R; the activation of AT1R may play an important role in promoting breast cancer growth, and AT1R blocker (ARB) may suppress the promotional effect on proliferation by antagonizing AT1R. The expression level of AT1R was found to be significantly upregulated in breast cancer cells by immunohistochemistry, but no correlation between AT1R expression and ER/PR/ Her-2 expression was observed. The AT1R(+)-MCF-7 cell line exhibited high expression of AT1R protein, and we generated the AT1R(-)-MCF-7 cell line using RNA interference. ARBs, and in particular irbesartan, effectively inhibited the effects of Ang II on cell proliferation, cell cycle development and downstream AT1R signaling events, including the activation of the Ras-Raf-MAPK pathway and the transcription factors $\mathrm{NF}-\kappa \mathrm{B}$ and CREB. Irbesartan also significantly altered p53, PCNA and cyclin D1 expression, which was also influenced by activated AT1R in AT1R(+)-MCF-7 cells. These results suggest that ARBs may be useful as a novel preventive and therapeutic strategy for treating breast cancer.
\end{abstract}

Correspondence to: Dr Hong Ren, Department of Oncosurgery, First Affiliated Hospital, Xi'an Jiaotong University, Xi'an, Shaanxi 710061, P.R. China

E-mail: andrewdu@126.com

Key words: angiotensin II type 1 receptor, proliferation, breast cancer cell, Ras, ERK, NF-кB, CREB, p53, PCNA, cyclin D1

\section{Introduction}

Breast cancer is a widespread health problem that affects women throughout the world. One in eight women in the USA will develop breast cancer during their lifetime (1). Internationally, breast cancer is the most commonly diagnosed cancer among women. Many risk factors for breast cancer are shared with cardiovascular diseases, such as having chronic stress or a high-fat diet. These risk factors have been well documented and associated with the renin-angiotensin system (RAS) in the development of breast cancer.

Angiotensin II (Ang II) is a peptide hormone that is the most important biological effector protein of the RAS. Ang II combines with high-affinity to $G$ protein coupled receptors in the plasma membrane. There are two subtypes of the Ang II receptor: angiotensin II type 1 receptor (AT1R) and angiotensin II type 2 receptor (AT2R). AT1R acts as a vascular contractive factor, which is important for cardiovascular function and the balance of water and electrolytes (2). AT2R binds to Ang II with high affinity, but this is not responsible for mediating any of the classical physiologic actions of Ang II, all of which involve AT1R (3). Recent studies have shown that almost every tissue has a local RAS that can regulate tissue growth and differentiation (4). With the exception of the classical circulative pathway, the RAS has been shown to be locally activated in most cancers, such as ovarian cancer, malignant melanoma, and sarcoma, which can cause the production of Ang II and upregulate the expression of AT1R (4-8). In addition, the local RAS in tissues may be connected with the occurrence and development of tumors.

The expression of AT1R is upregulated in most tumors, and Ang II affects cells by activating AT1R. After combining with AT1R, Ang II can interact with several genes (9-12) that promote the division and proliferation of tumor cells and inhibit cell differentiation (10,13-15). In addition, it has been shown that local Ang II can promote the proliferation of tumor cells (16-18).

After activation by Ang II, AT1R can activate the mitogenactivated protein kinase (MAPK) pathway, which plays an important role in cell proliferation (19). Activated AT1R can 
also activate RAS, which can then activate Raf and lead to the activation of a cascade of signaling proteins, including MEK and ERK. ERK1/2 has been shown to be involved in the proliferation of tumor cells. Through phosphorylation, ERK is activated to p-ERK, which can then activate downstream transcription factors, including $N F-\kappa B$ and CREB. Activated $\mathrm{NF}-\kappa \mathrm{B}$ and $\mathrm{CREB}$ can regulate the expression of a number of downstream genes, and a dysregulated signaling cascade of these factors can result in uncontrolled cell division and proliferation of tumor cells (20).

Previous studies have shown that specific AT1R antagonists can inhibit the induction of growth and proliferation of tumor cells by Ang II. One study showed that losartan, an AT1R blocker (ARB), can inhibit the growth of rat glioma cells, in which AT1R is highly expressed (21). Therefore, Ang II and AT1R play an important role in the growth of tumor cells, and the use of specific AT1R antagonists may be a viable strategy for blocking tumor growth in breast cancer.

Based on previous studies that have explored the relationship between tumors and Ang II/AT1R signaling, we assessed whether Ang II can promote the proliferation of breast cancer through the activation of AT1R. We also explored whether Ang II-mediated proliferation of breast cancer cells can be inhibited by an ARB by assessing the inhibition of downstream effectors of Ang II/AT1R signaling, including the activation of the RAS-ERK pathway and transcription factors NF- $\kappa \mathrm{B}$ and CREB, the subsequent upregulation of p53 expression, downregulation of PCNA, and cyclin D1 expression.

\section{Materials and methods}

Reagents. Dulbecco's modified Eagle's medium (DMEM), Roswell Park Memorial Institute 1640 (RPMI-1640) medium, and fetal bovine serum (FBS) were purchased from Gibco (Grand Island, NY). Recombinant Ang II and the ARBs (irbesartan, losartan, valsartan and candesartan) were purchased from Sigma Chemical Co. (St. Louis, MO). The 3-(4,5-dimethylthiazol-2-yl)-2,5-diphenyl-tetrazoliumbromide (MTT) reagent was obtained from Sigma Chemical Co. The propidium iodide (PI) and Annexin V-FITC kits were obtained from BD Biosciences (San Jose, CA). Primary antibodies against AT1R, GTPase-Ras (p-Ras), GDPase-Ras (Ras), p-Erk, Erk, p-PI3K, PI3K, p-Akt, Akt, NF-кB-p65, p53, PCNA, and cyclin D1 were purchased from Abcam (Cambridge, MA). Primary antibodies against p-CREB and CREB were purchased from Cell Signaling Technology (Beverly, MA). Nitrocellulose membranes and protein A agarose beads were purchased from Millipore (Bedford, MA). The BCA assay kit and the chemiluminescence kit were purchased from Pierce (Rockford, IL).

Immunohistochemistry. Sections of cancerous and paired normal breast tissues were obtained from 65 patients with operable breast cancer between February 2007 and September 2010 at the first affiliated hospital of medical college of Xi'an Jiaotong University. The clinical trial was approved by the Ethics Committee of the First Affiliated Hospital of Medical College of Xi'an Jiaotong University. Informed consent was obtained from all patients prior to the start of this study. The samples were dewaxed and hydrated in graded alcoholic solutions and distilled water. For histopathology, routine hematoxylin and eosin $(\mathrm{H} \& \mathrm{E})$ staining was conducted. For immunohistochemical staining of AT1R, a steptavidin-biotin complex (SABC) kit was used according to the manufacturer's instructions. Briefly, endogenous peroxidase activity was quenched with $0.5 \%$ hydrogen peroxide in methanol for $30 \mathrm{~min}$, and non-specific binding was blocked by incubating the samples with $5 \%$ normal goat serum for $30 \mathrm{~min}$. The sections were then incubated with primary antibodies overnight at $4^{\circ} \mathrm{C}$ followed by incubation with the appropriate biotinylated secondary antibody conjugated to horseradish peroxidase (HRP) for $30 \mathrm{~min}$ at room temperature, followed by incubation with avidin/biotin complexes for $30 \mathrm{~min}$ at room temperature. then washed 3 times in PBS for 5 min each. The immunoreactivity was visualized using 3,3-diaminobenzidine (DAB). Sections were counterstained with H\&E and then dehydrated in graded alcohol solutions. The scores were calculated as the number of stained cells divided by the total number of cells counted. Ten high-power fields (magnification, $\mathrm{x} 400$ ) per slide were calculated and the results were averaged. Unequivocal staining of the cytoplasm in $>50 \%$ of the cells was considered as positive.

Cell lines and culture conditions. The human breast cancer cell lines MCF-7, T47D, ZR-75-30, MDA-MB231, MDA-MB-435 and MDA-MB-468 were generously provided as gifts by Professor Huang Chen (Key Laboratory of Environment and Genes Related to Disease, Ministry of Education, Xi'an Jiaotong University). The human breast cancer cell lines MCF-7, MDA-MB-435 and MDA-MB-468 were cultured in DMEM with $10 \%(\mathrm{v} / \mathrm{v})$ heat-inactivated FBS, penicillin $(100 \mathrm{U} / \mathrm{ml})$ and streptomycin $(100 \mathrm{mg} / \mathrm{ml})$. The human breast cancer cell lines T47D, ZR-75-30 and MDA-MB-231 were cultured in RPMI-1640 with $10 \%$ (v/v) heat-inactivated FBS, penicillin $(100 \mathrm{U} / \mathrm{ml})$, and streptomycin $(100 \mathrm{mg} / \mathrm{ml})$. All cell lines were grown at $37^{\circ} \mathrm{C}$ in $5 \%$ $\mathrm{CO}_{2}$ and $95 \%$ relative humidity. Before each experiment, cells were seeded at a density of $5 \times 10^{4}$ cells $/ \mathrm{cm}^{2}$.

Analysis of protein expression by western blot analysis. Total protein was extracted from cultured cells in radio-immunoprecipitation assay (RIPA) lysis buffer on ice for $20 \mathrm{~min}$. Insoluble materials were removed by centrifugation at $12,000 \mathrm{rpm}$ for $15 \mathrm{~min}$ at $4^{\circ} \mathrm{C}$. The supernatants were then collected and the total protein concentrations were measured using the BCA assay kit according to the manufacturer's instructions. Clarified protein lysates (30-80 mg) were electrophoretically resolved on a denaturing SDS polyacrylamide gel (8-12\%) and electrotransferred onto nitrocellulose membranes. The membranes were initially blocked in 5\% non-fat dry milk in Tris-buffered saline (TBS) for $2 \mathrm{~h}$ and then probed with specific primary antibodies against AT1R (ab9391), GTPase-Ras (p-Ras, ab16881), GDPase-Ras (Ras, ab16907), p-Erk (ab79483), Erk (ab38011), p-PI3K(ab8933), PI3K (ab8805), p-Akt (ab38449), Akt (ab8805), NF-кB-p65 (ab7970), p-CREB (ab30651), CREB (ab7540), p53 (ab26), PCNA (ab29) and cyclin D1 (ab6152) (Abcam). After co-incubation with the primary antibodies at $4^{\circ} \mathrm{C}$ overnight, membranes were blotted with the secondary antibody for $2 \mathrm{~h}$ at room temperature. Immunopositive bands were detected using an enhanced chemiluminescence (ECL) 
detection system (Amersham Bioscience, Piscataway, NJ, USA) and autoradiography. The western blot anaslysis was scored as positive if the band of interest was present at the expected molecular weight. All analyses were performed in triplicate.

Construct ATIR negative MCF-7 cell line by RNA interference. The shRNA sequences (5'-GATCC-atgattctcaactct-T TCAAAGACG-tactaagagttgaga-TTTTTTGTCGAC-A-3') for AT1R were designed and synthesized by GenePharma. The shRNA was cloned into the carrier plasmid pGenesil 1.1, which contained the stable selection marker (Neogene). The resulting plasmid was labeled pGenesil-AT1R-shRNA and confirmed by restriction enzyme digestion and agarose gel electrophoresis. DNA sequencing also confirmed the correct sequence of the plasmid. The pGenesil-AT1R-shRNA plasmid was then transfected into MCF-7 cells using Lipofectamine 2000 according to the manufacturer's instructions. After $48 \mathrm{~h}$, the cells were placed in selection media containing $400 \mu \mathrm{g} / \mathrm{ml}$ Geneticin (G418; Gibco, Grand Island, NY). The reduction in AT1R protein expression was detected by western blot analysis.

MTT assay. The effects of Ang II on cell proliferation, as well as the inhibitory effects of ARBs were assessed by the colorimetric 3-[4,5-dimethylthiazol-2-yl]-2,5-diphenyltetrazolium bromide (MTT) assay. Cells were seeded in a 96-well plate at a concentration of $5 \times 10^{3}$ per well on the day before the experiment. Ang II (0-1000 nM) was added to the cells the next day and incubated for $24 \mathrm{~h}$ with Ang II (0-1000 nM). After the incubation, MTT was added to each well and the cells were incubated for an additional $4 \mathrm{~h}$ at $37^{\circ} \mathrm{C}$. DMSO $(150 \mu \mathrm{l})$ was subsequently added and the absorption value was measured at a wavelength of $492 \mathrm{~nm}$. For assessment of the inhibitory effect of ARBs on Ang II-mediated proliferation, the same assay was performed using an optimal concentration of $100 \mathrm{nM}$ Ang II as previously determined. On the day of the experiment, the seeded cells were incubated for $30 \mathrm{~min}$ with 0.1-100 $\mu \mathrm{M}$ irbesartan, losartan, valsartan, or candesartan prior to the addition of $100 \mathrm{nM}$ Ang II. All other procedural steps were performed exactly as described above. The assays were performed in triplicate.

Flow cytometry. AT1R(+)-MCF-7 and AT1R(-)-MCF-7 cells were divided into the following 4 groups each: i) control group, ii) $100 \mathrm{nM}$ Ang II, iii) $10 \mu \mathrm{M}$ irbesartan, and iv) a combination treatment, where $10 \mu \mathrm{M}$ irbesartan was added $30 \mathrm{~min}$ before treatment with $100 \mathrm{nM}$ Ang II. The groups received the above treatments $24 \mathrm{~h}$ before flow cytometric analysis. On the day of the experiment, $5 \times 10^{5}$ cells were collected, washed two times with PBS, and then prepared for flow cytometric analysis using the following procedure. First, the cells were resuspended in $500 \mu \mathrm{l}$ binding buffer, and then $5 \mu \mathrm{l}$ of Annexin V-FITC and $10 \mu \mathrm{l}$ of PI were added. The mixture was gently vortexed and then incubated for $15 \mathrm{~min}$ at room temperature $\left(20-25^{\circ} \mathrm{C}\right)$ in the dark. The cells were analyzed by flow cytometry within $1 \mathrm{~h}$ of incubation and all analyses were performed in triplicate.

For cell cycle analysis, the same treatment groups described above were used. Briefly, $5 \times 10^{5}$ cells were collected, washed twice with PBS, and then fixed with ice-cold $70 \%$
Table I. AT1R expression and clinicopathological characteristics of patients with operable breast cancer.

\begin{tabular}{lcccc}
\hline Variables & $\mathrm{n}$ & $\begin{array}{c}\text { AT1R positive } \\
\text { expression n (\%) }\end{array}$ & $\chi^{2}$ & P-value \\
\hline ER & & $19(48.9)$ & 1.456 & $>0.05$ \\
Positive & 39 & $12(46.1)$ & & \\
Negative & 26 & $19(48.9)$ & 1.456 & $>0.05$ \\
PR & & $12(46.1)$ & & \\
Positive & 39 & $17(47.2)$ & 2.097 & $>0.05$ \\
Negative & 26 & $14(48.3)$ & & \\
Her-2 & & & & \\
Positive & 36 & & & \\
Negative & 29 & & & \\
\hline
\end{tabular}

ethanol for $24 \mathrm{~h}$ at $4^{\circ} \mathrm{C}$. The fixed cells were then stained with PI for $30 \mathrm{~min}$ at $37^{\circ} \mathrm{C}$, and the samples were analyzed on a flow cytometer. Cell cycle analysis of DNA content was performed with the MultiCycle software. All analyses were performed in triplicate.

Immunoprecipitation. For the immunoprecipitation assay, AT1R(+)-MCF-7 cells were treated with Ang II and irbesartan for $24 \mathrm{~h}$ and then harvested in RIPA buffer on ice for $20 \mathrm{~min}$. Insoluble materials were removed by centrifugation at $12,000 \mathrm{rpm}$ for $15 \mathrm{~min}$ at $4^{\circ} \mathrm{C}$. The samples were then incubated with an anti-AT1R antibody at $4^{\circ} \mathrm{C}$ overnight with gentle rotation. The next day, $10 \mu \mathrm{l}$ protein $\mathrm{A}$ agarose beads washed in RIPA lysis buffer 3 times were added to the lysates containing the anti-AT1R antibody and incubated for an additional $2-4 \mathrm{~h}$ at $4^{\circ} \mathrm{C}$. The protein A agarose beads with bound antibody were then washed 3 times and boiled in SDS loading buffer for $5 \mathrm{~min}$ at $95^{\circ} \mathrm{C}$. The samples were resolved by SDS-PAGE and western blot analysis as described above.

Statistical analysis. All statistical analyses were performed using the SPSS13.0 software (IBM, USA). The results of the immunohistochemistry were analyzed by the $\chi^{2}$ test, and all other results were presented as the mean \pm standard deviation (SD) of experiments performed in triplicate. The differences between the groups were assessed by the analysis of variance (ANOVA) test. A P-value $<0.05$ was considered statistically significant.

\section{Results}

AT1R expression analysis in breast cancer. The expression level of AT1R was significantly upregulated in breast cancer samples compared to paired normal breast tissue by immunohistochemistry (IHC) (Fig. 1A and B; P<0.05). These results suggested that AT1R may have a role in tumorigenesis. Importantly, we did not detect a correlation between AT1R expression and ER/PR/Her-2 expression by IHC, which are typical biomarkers of breast cancer (Table I). 
A

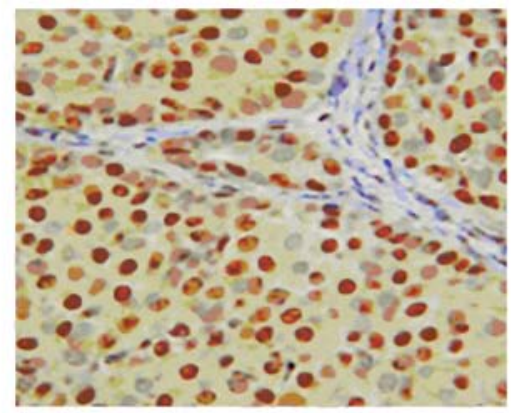

B

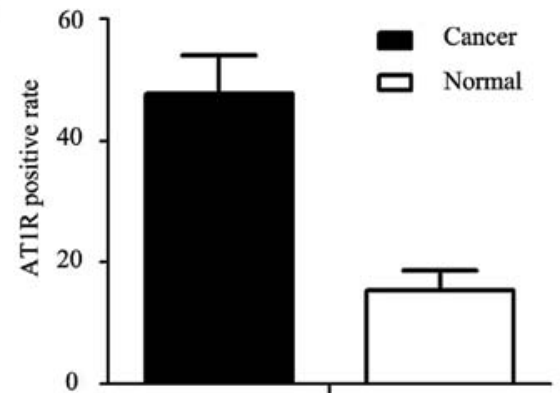

AT1R expression in breast cancer and normal breast tissue

$\mathrm{C}$

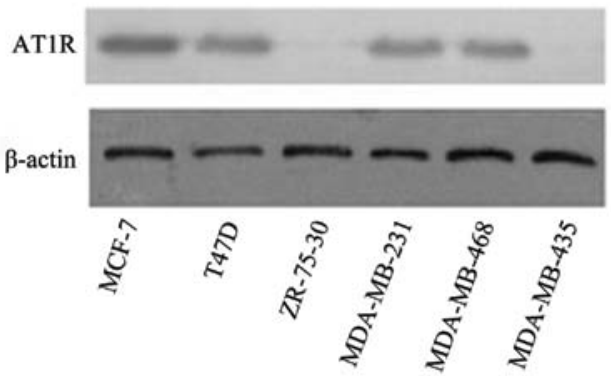

D

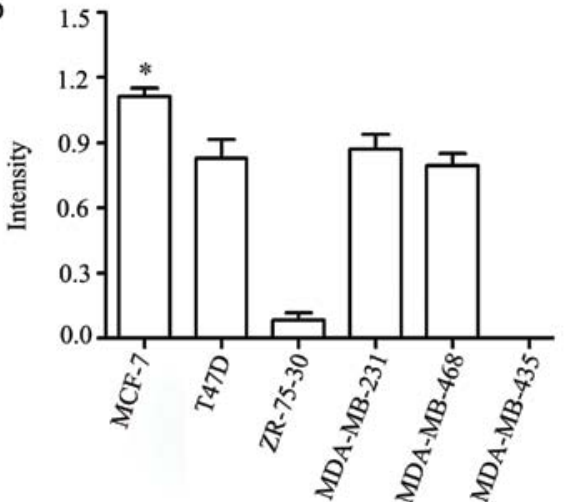

AT1R protein expression in breast cancer cell lines

Figure 1. Analysis of AT1R expression in cancerous and paired non-cancerous tissues of patients with breast cancer by immunohistochemistry (A and B) and in the breast cancer cell lines MCF-7, T47D, ZP-75-30, MDA-MB-231, MDA-MB-468, and MDA-MB-435 by western blot analysis (C and D). AT1R expression was positive and upregulated in the breast cancer tissue samples relative to the paired normal breast tissues (magnification, $\mathrm{x} 400 ; \mathrm{P}<0.05$ ). The highest AT1R protein expression of the breast cancer cell lines was in MCF-7 $(\mathrm{P}<0.05)$.

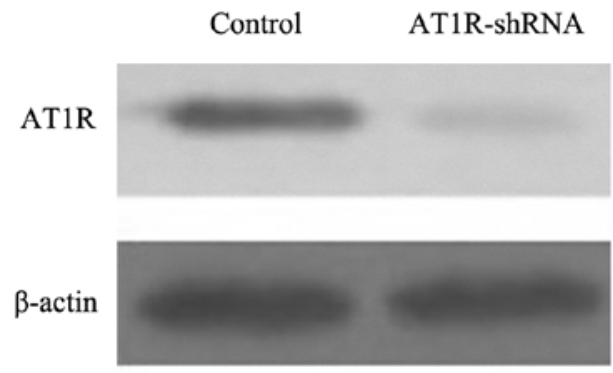

B

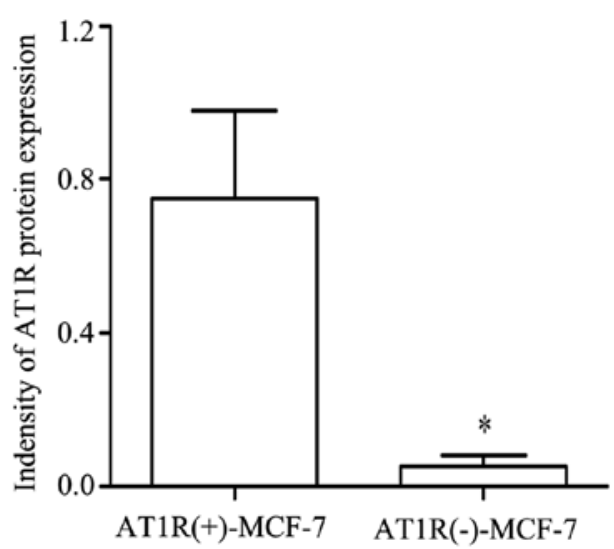

Figure 2. Detection of AT1R protein expression in MCF-7 cells after shRNA transfection. The expression of AT1R in MCF-7 cells transfected with pGenesil-AT1R-shRNA was significantly reduced compared to untransfected MCF-7 cells $(\mathrm{P}<0.05)$. We regarded MCF-7 cells transfected with pGenesil-AT1R-shRNA as negative for AT1R expression.

ATIR protein expression levels in breast cancer cell lines. We next assessed the protein expression level of AT1R in several breast cancer cell lines. Based on western blot analysis, we found that the cell lines MCF-7, T47D, ZP-75-30, MDA-MB-231 and MDA-MB-468 all had elevated expression levels of AT1R, but MDA-MB-435 cells were negative for AT1R (Fig. 1C and D). The highest expression of AT1R was found in MCF-7 cells (Fig. $1 \mathrm{C}$ and $\mathrm{D} ; \mathrm{P}<0.05$ ). Therefore, we chose MCF-7 cells for the additional experiments.
Treatment of MCF-7 cells with Ang II and ARBs. In order to assess the effects of Ang II and ARBs on MCF-7 cells, we first generated the MCF-7 cell line stably expressing an shRNA construct (pGenesil-AT1R-shRNA) that significantly reduced AT1R expression levels. As shown in Fig. 2, the resulting cell line effectively reduced AT1R expression to very low levels compared to the untransfected control (Fig. 2; $\mathrm{P}<0.05$ ).

We next determined the optimal concentration of Ang II (0-1000 nM) for stimulation of MCF-7 proliferation. After 
A

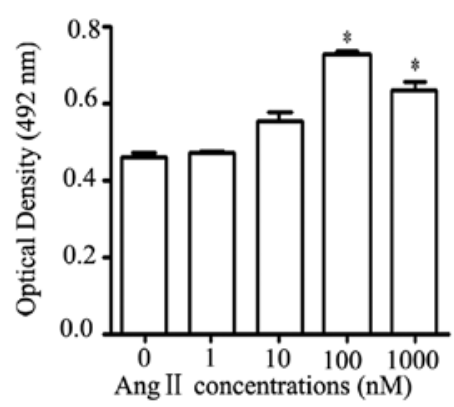

$\mathrm{C}$

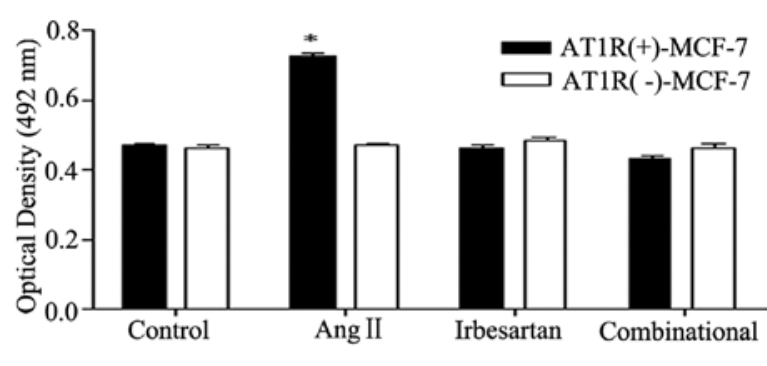

Proliferation of MCF-7 cells treated with Ang II and irbesartan

B

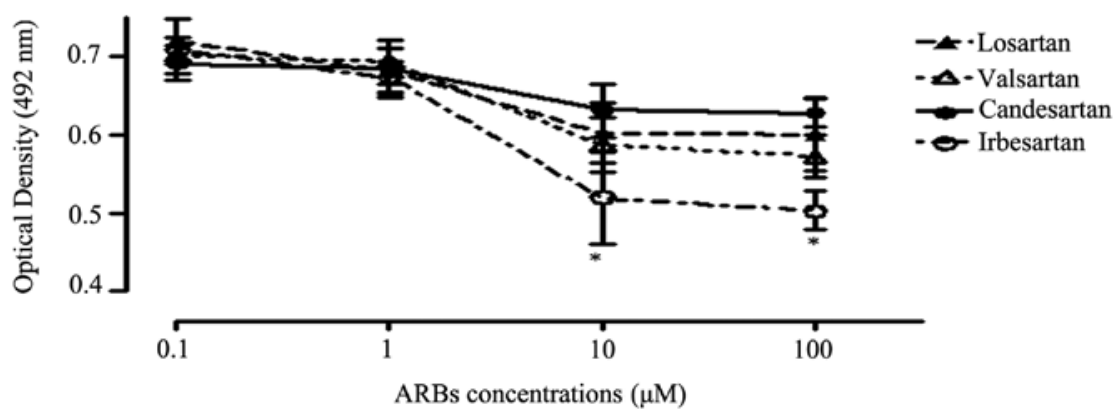

Figure 3. MTT assay of AT1R(-)-MCF-7 and AT1R(+)-MCF-7 cells. (A) After treatment with the indicated concentrations of Ang II for $24 \mathrm{~h}$, the proliferation of MCF-7 cells was detected by MTT assay. The most robust cell proliferation was observed between concentrations of 100 and $1000 \mathrm{nM}$ of Ang II (P<0.05). (B) Irbesartan, losartan, valsartan, and candesartan were tested for the ability to inhibit Ang II effects on MCF-7 cells using the MTT assay. Irbesartan induced the greatest inhibition of Ang II activity at an optimal concentration between 10 and $100 \mu \mathrm{M}(\mathrm{P}<0.05)$. (C) AT1R(-)-MCF-7 cells and AT1R(+)-MCF-7 cells were untreated or treated for $24 \mathrm{~h}$ with $100 \mathrm{nM}$ Ang II (Ang II group), $10 \mu \mathrm{M}$ irbesartan (irbesartan group), or $10 \mu \mathrm{M}$ irbesartan added $30 \mathrm{~min}$ before $100 \mathrm{nM}$ Ang II treatment (combinational group). Ang II can stimulated cell proliferation in AT1R(+)-MCF-7 cells, but had no effect in AT1R(-)-MCF-7 cells $(\mathrm{P}<0.05)$. Meanwhile, the control groups and irbesartan groups of two cell lines were compared, both were no difference in cell proliferation $(\mathrm{P}>0.05)$. In AT1R(+)-MCF-7 cell line, Ang II can promote cell proliferation compared to other groups ( $\mathrm{P}<0.05)$, additionally, there were no difference in cell proliferation between combinational group, irbesartan group and control group ( $\mathrm{P}>0.05)$. But in AT1R(-)-MCF-7 cell line, there were no differences in cell proliferation in each group $(\mathrm{P}>0.05)$.

treating the cells with increasing concentrations of Ang II for $24 \mathrm{~h}$, we found that exposure to Ang II induced cell proliferation at concentrations comparable to the untreated control. In addition, a concentration between 100 and $1000 \mathrm{nM}$ induced the greatest proliferation of MCF-7 cells (Fig. 3A; $\mathrm{P}<0.05$ ). Moreover, the pre-incubation of the cells with irbesartan, losartan, valsartan, or candesartan prior to the addition of Ang II inhibited Ang II-mediated cell proliferation of MCF-7 cells in a dose-dependent manner (Fig. 3B). We also found that irbesartan induced the greatest inhibition of Ang II-mediated proliferation compared to the other ARBs, with an optimal concentration between 10 and $100 \mu \mathrm{M}$ (Fig. 3B; $\mathrm{P}<0.05$ ).

In AT1R(-)-MCF-7 and AT1R(+)-MCF-7 cell lines treated with Ang II and irbesartan for $24 \mathrm{~h}$, we found that Ang II stimulated cell proliferation in AT1R(+)-MCF-7 cells, but had no effect on AT1R(-)-MCF-7 cells (Fig. 3C; $\mathrm{P}<0.05$ ). Importantly, the control and irbesartan treatment groups of the two cell lines had no difference in cell proliferation, and treatment of AT1R(+)-MCF-7 cells with both Ang II and irbesartan blocked the effects of Ang II on these cells (Fig. 3C; $\mathrm{P}<0.05$ ). These results indicated that the increased proliferation effect of Ang II on MCF-7 cells requires positive AT1R expression. Moreover, the expression of AT1R alone or treatment with specific ARBs had no influence on cell proliferation in these cells. Therefore, Ang II-mediated proliferation occurred through the activation of AT1R.
Cell cycle analysis of MCF-7 cells treated with Ang II and irbesartan. Cell cycle analysis of AT1R(-)-MCF-7 cells and AT1R(+)-MCF-7 cells treated with $100 \mathrm{nM}$ Ang II for $24 \mathrm{~h}$ showed that treatment of AT1R(+)-MCF-7 cells decreased the percentage of cells in G0-G1 and increased the percentage of cells in S phase compared to AT1R(-)-MCF-7 cells treated with Ang II (Fig. 4; $\mathrm{P}<0.05$ ). These results indicated that Ang II can promote the G1/S transition, which is dependent on AT1R, and thereby develop induce cell proliferation. Importantly, the control and irbesartan groups showed no difference in cell cycle phase distribution in the two cell lines (Fig. 4; P>0.05). In addition, we found no difference in the cell cycle distribution of AT1R(+)-MCF-7 cells treated with both Ang II and irbesartan, which indicated that the effects of Ang II on the cell cycle can be suppressed by this ARB by antagonizing AT1R (Fig. 4; P>0.05).

Apoptotic analysis of MCF-7 cells treated with Ang II and irbesartan. We next assessed AT1R(-)-MCF-7 and AT1R(+)-MCF-7 cells treated with Ang II, irbesartan, or Ang II + irbesartan to determine if these factors had any effect on apoptosis. No difference in apoptosis was observed in any of the treatment groups in either cell line (Fig. 5; P>0.05). There was also no difference in apoptosis rates when each group of the two cell lines was compared to other groups of the same cell line, or when the cell lines were treated with irbesartan alone (Fig. 5; $\mathrm{P}>0.05)$. These results indicated that irbesartan alone cannot 
A
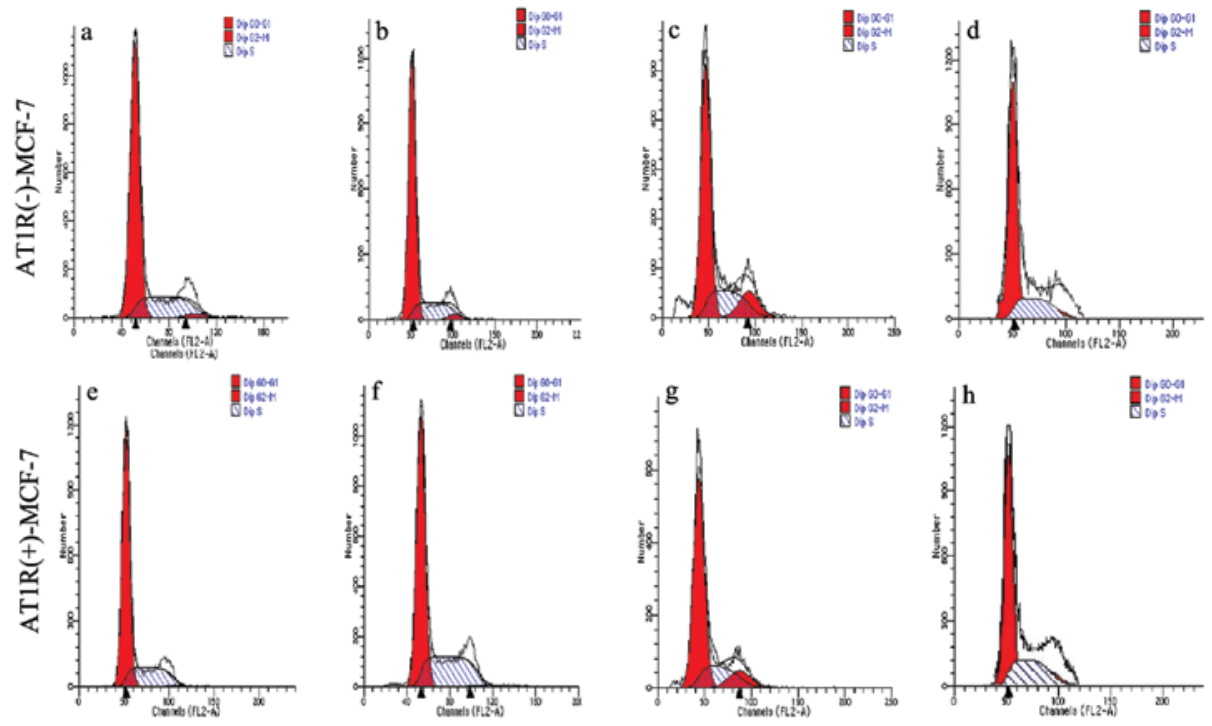

B
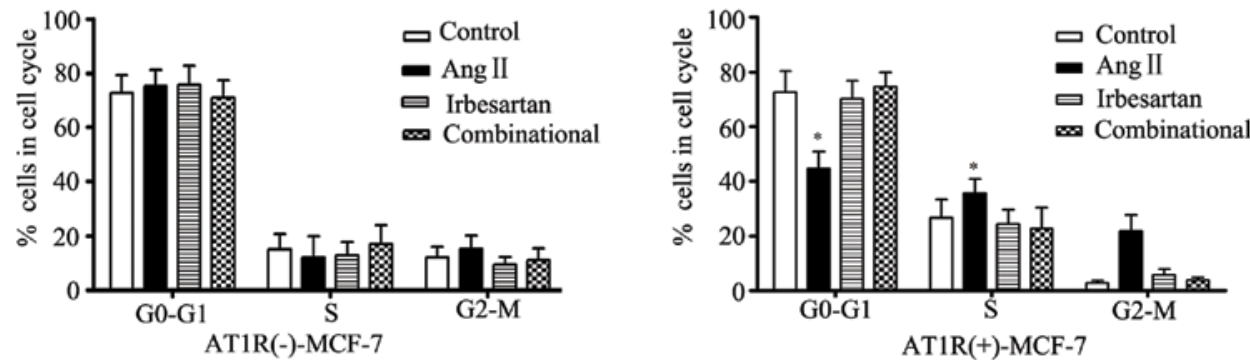

Figure 4. Cell cycle analysis by flow cytometry of AT1R(-)-MCF-7 and AT1R(+)-MCF-7 cells treated with Ang II and irbesartan for $24 \mathrm{~h}$ (A). Two cell lines were untreated (a and e) or treated for $24 \mathrm{~h}$ with $100 \mathrm{nM}$ Ang II (b and f), $10 \mu \mathrm{M}$ irbesartan (c and g), or $10 \mu \mathrm{M}$ irbesartan added $30 \mathrm{~min}$ before $100 \mathrm{nM}$ Ang II treatment ( $\mathrm{d}$ and $\mathrm{h}$ ) for $24 \mathrm{~h}$. (B) Bar graph quantification of the cell cycle plots from A. In AT1R(+)-MCF-7 cells exposed to Ang II, the percentages of G0-G1 phase decreased, while the percentages of S phase increased compared to Ang II group of AT1R(-)-MCF-7 cell line (P<0.05). Control groups and irbesartan groups of two cell lines were compared, both no difference in cell cycle phase distribution (P>0.05). Each group of AT1R(-)-MCF-7 cell line were compared with each other, no difference in cell cycle distribution ( $\mathrm{P}>0.05)$. In AT1R(+)-MCF-7 cell line, Ang II can induce G1/S phase development compared to other groups $(\mathrm{P}<0.05)$, meanwhile, there were no difference in cell cycle distribution in combinational group, irbesartan group and control group $(\mathrm{P}>0.05)$.

induce apoptosis of MCF-7 cells, and that the negative effect of this ARB on Ang II-mediated proliferation is not a result of increased apoptosis.

Expressions of downstream effector proteins of Ras signaling. The results showing that Ang II promotes cell proliferation of MCF-7 cells through AT1R activation suggested that downstream signaling factors of the AT1R pathway may also be affected as a result of the Ang II effects. Therefore, we examined the expression of Ras, p-Ras, Erk, p-Erk, PI3K, p-PI3K, Akt, p-Akt, NF-кB-P65, CREB, p-CREB, p53, PCNA, and cyclin D1 by western blot analysis of the AT1R(-)-MCF-7 and AT1R(+)-MCF-7 cell lines treated with Ang II, irbesartan, or Ang II + irbesartan. As shown in Fig. 6, Ang II significantly increased the expression of p-Ras, p-Erk, NF- $\mathrm{KB}-\mathrm{P} 65$, p-CREB, PCNA, and cyclin D1 and decreased p53 expression in the AT1R(+)-MCF-7 cell line compared to AT1R(-)-MCF-7 cells treated with Ang II $(\mathrm{P}<0.05)$. No difference in protein expression levels between the two cell lines was observed in the irbesartan-treated group, and irbesartan blocked the
Ang II-mediated effects on the expression of these proteins in AT1R(+)-MCF-7 cells (Fig. 6; P>0.05). Therefore, these data indicated that irbesartan can suppress the effects of Ang II on the expression of related proteins in MCF-7 cells by antagonizing AT1R.

Co-immunoprecipitation of ATIR and p-Ras. The upregulation of p-Ras in AT1R(+)-MCF-7 cells by Ang II treatment suggested that the effects of AT1R signaling may occur through activated Ras, since this protein is known to interact with AT1R. Therefore, we performed a co-immunoprecipitation assay using an anti-AT1R antibody to assess whether the association of activated Ras (p-Ras) with the receptor was increased after Ang II treatment. As shown in Fig. 7, the interaction of p-Ras with AT1R was significantly increased in AT1R(+)-MCF-7 cells treated with Ang II compared to the other groups $(\mathrm{P}<0.05)$. Importantly, $\mathrm{p}$-Ras did not immunoprecipitate with AT1R in the control or irbesartan treated groups, and the addition of irbesartan blocked the Ang II-mediated effects and prevented the co-immunoprecipitation of $\mathrm{p}$-Ras 

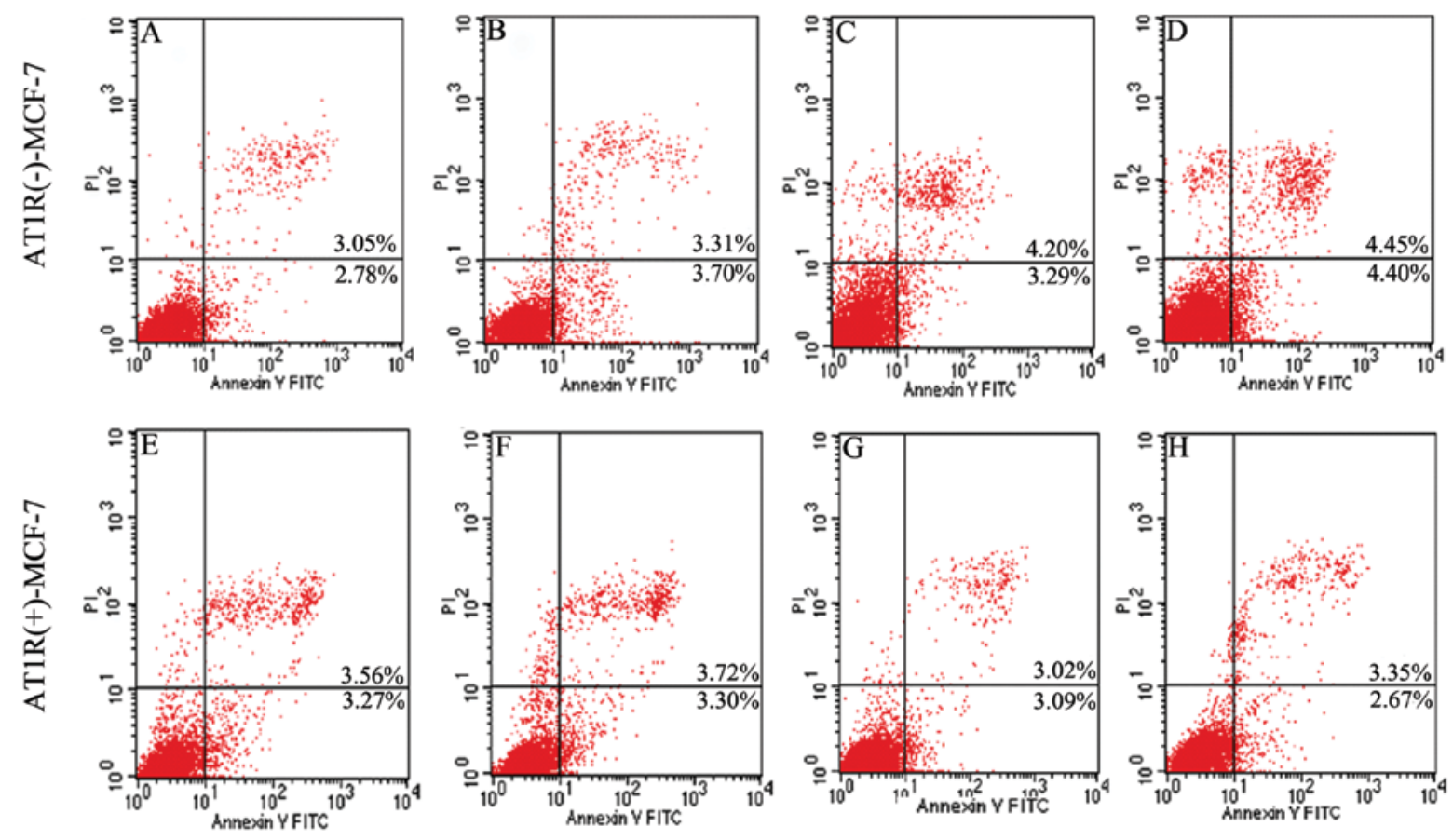

Figure 5. Flow cytometry assessment of apoptosis rates of AT1R(-)-MCF-7 and AT1R(+)-MCF-7 cells after treatment with Ang II or irbesartan for 24 h. AT1R (-)-MCF-7 and AT1R(+)-MCF-7 cells were not treated (A and E) or treated with $100 \mathrm{nM}$ Ang II (B and F), $10 \mu \mathrm{M}$ irbesartan (C and G), or $10 \mu \mathrm{M}$ irbesartan added $30 \mathrm{~min}$ before $100 \mathrm{nM}$ Ang II treatment (D and H) for $24 \mathrm{~h}$. Each group of two cell lines were compared, no difference in apoptosis rate (P>0.05). Meanwhile, each group of the two cell lines were compared to other groups of the same cell line, no difference in apoptosis rate (P>0.05).

(Fig. 7). These results indicated that AT1R interacts with p-Ras after stimulation with Ang II, and therefore Ang II can activate RAS through the activation of AT1R signaling. These results also suggested irbesartan can inhibit Ang II-mediated activation of the RAS by blocking AT1R activation.

\section{Discussion}

Recent research has shown that activated RAS can be present in both normal and tumor tissues. Activated RAS is associated with the development of hypertension, diabetes, renal insufficiency, heart failure, and other cardiovascular diseases, and also plays an important role in tumorigenesis and development (22). Previous studies assessing the relationship between RAS and tumor development have shown that AT1R expression is higher in some tumor types compared to normal tissue $(22,23)$. Other studies have shown that the expression of AT1R is upregulated in several tumor types, including laryngeal, prostate, ovarian, keratoacanthoma, glioma, squamous cell carcinoma, cervical, bladder, choriocarcinoma, pancreatic, endometrial, gastric, and others (5-7,14,15,24-28). In addition, Ang II has been shown to be an important factor in tumor growth and angiogenesis through the activation of AT1R $(6,29)$. AT1R in combination with Ang II can promote the growth and proliferation of tumor cells through the activation of MAPK (19). Moreover, activated AT1R can activate RAS, which it turn activates the Ras-Raf-MAPK pathway leading to the phosphorylation of ERK and the subsequent regulation of $N F-\kappa B$ and CREB downstream gene regulation and the promotion of tumor cell proliferation (20).

Studies have shown that ARB can suppress the positive effect of Ang II on cell growth and proliferation. Studies by Zhao et al and Muscella et al have shown that Losartan and other AT1R blockers, such as DuP 753, can inhibit Ang II-mediated growth of breast cancer cells $(30,31)$. In addition, candesartan can suppress Ang II-mediated proliferation of prostate cancer cells (24), and losartan inhibits the growth of rat C6 glioma cells in vitro and in vivo (21). Importantly, these studies have shown that Ang II and AT1R play an important role in tumor growth, and AT1R antagonists may be an effective method for treating tumors. Our study indicated that ARBs, in particular irbesartan, can effectively block the effects of Ang II on cell proliferation, and the expression of proteins and transcription factors associated with cell proliferation in the breast cancer cell line MCF-7. In addition, our research showed that Ang II-induced AT1R activation induces the activation of RAS, which can result in several downstream effects on cell proliferation. We found that irbesartan could block AT1R activation and the effects of Ang II in these cells, thereby preventing the activation of RAS and other downstream events.

Our IHC and western blot results indicated that AT1R protein expression is elevated in human breast tissue samples relative to paired normal controls and was also highly expressed in several breast cancer cell lines, including MCF-7. However, there was no correlation between AT1R expression and ER/PR/Her-2 expression, which is a typical biomarker of breast cancer. In our experiments, Ang II promoted the proliferation of MCF-7 cells, and four ARBs tested were found to inhibit the effects of Ang II, including irbesartan, losartan, valsartan, and candesartan. From these analyses, we found that irbesartan had the strongest inhibitory effect on Ang II. In addition, we successfully constructed an AT1R(-)-MCF-7 cell line by stably expressing an shRNA specific for AT1R, and 


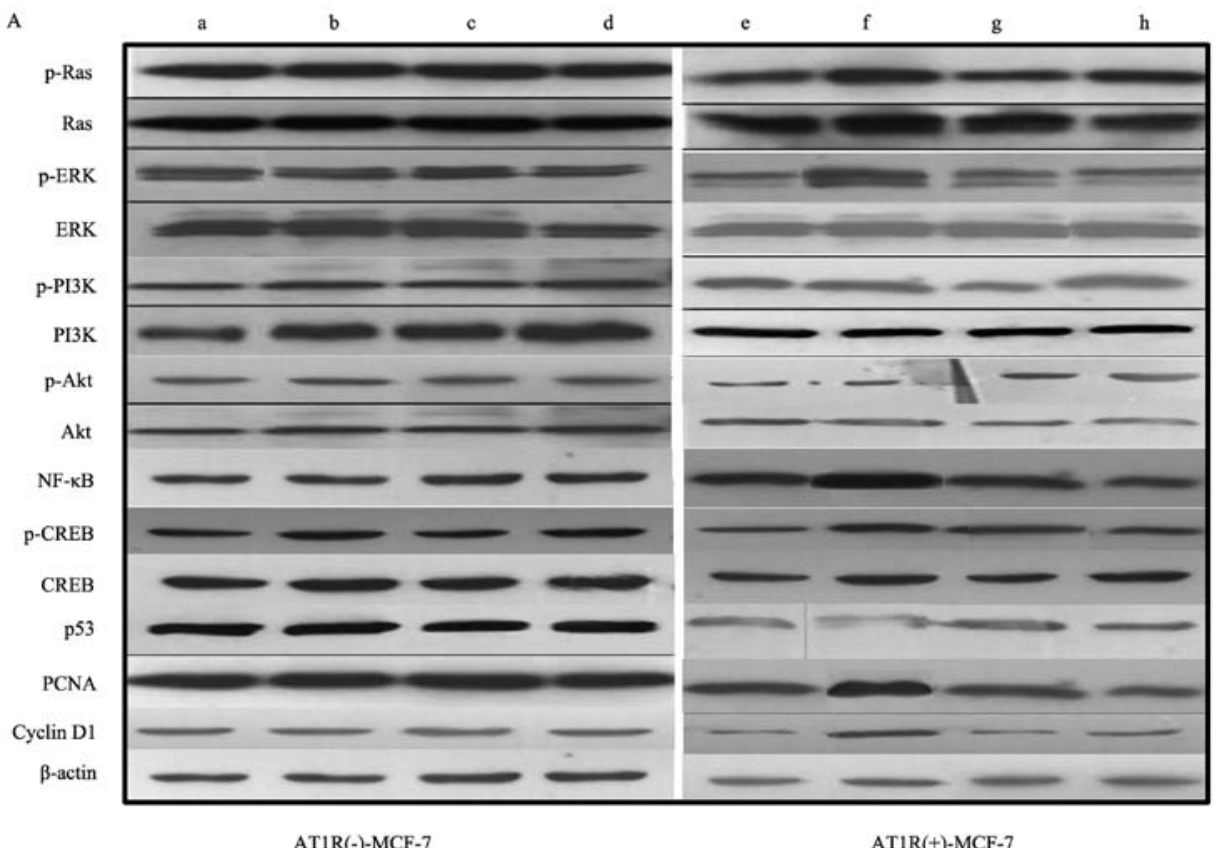

B
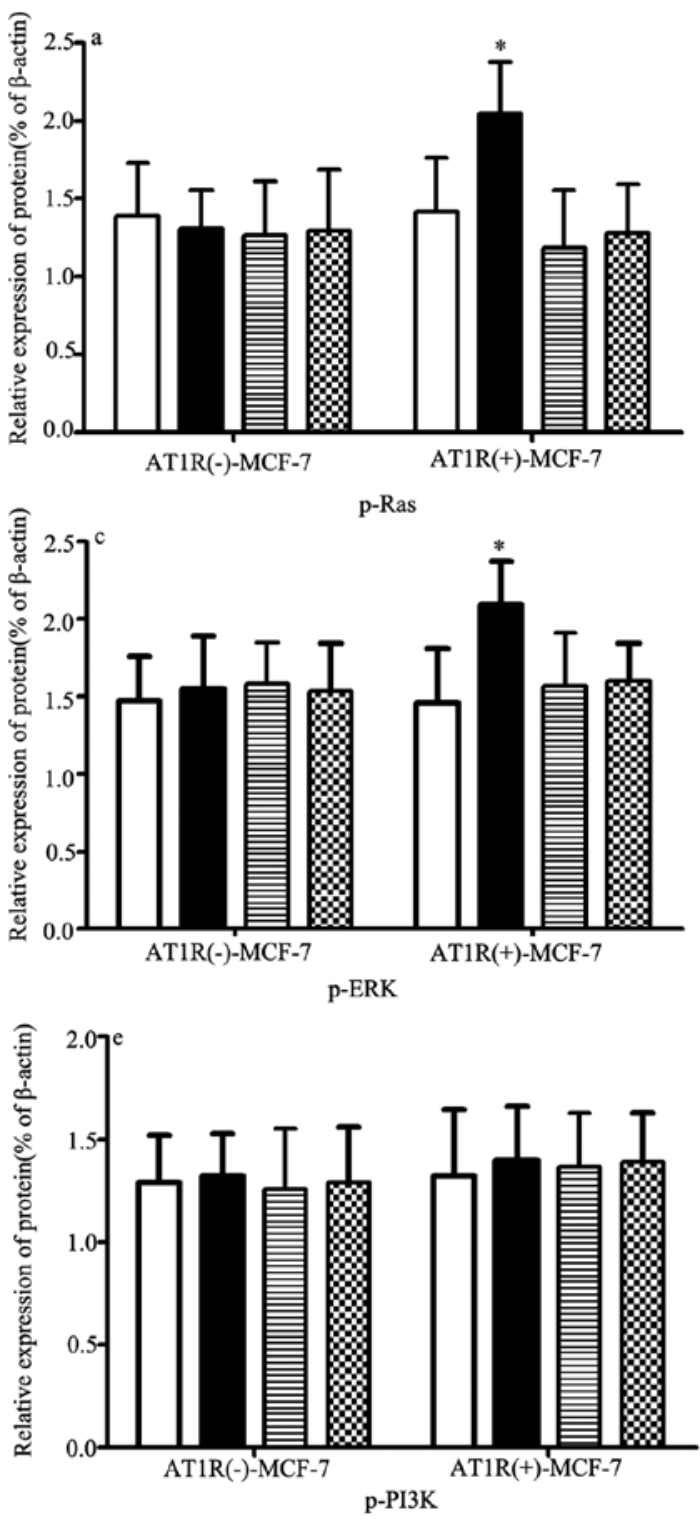
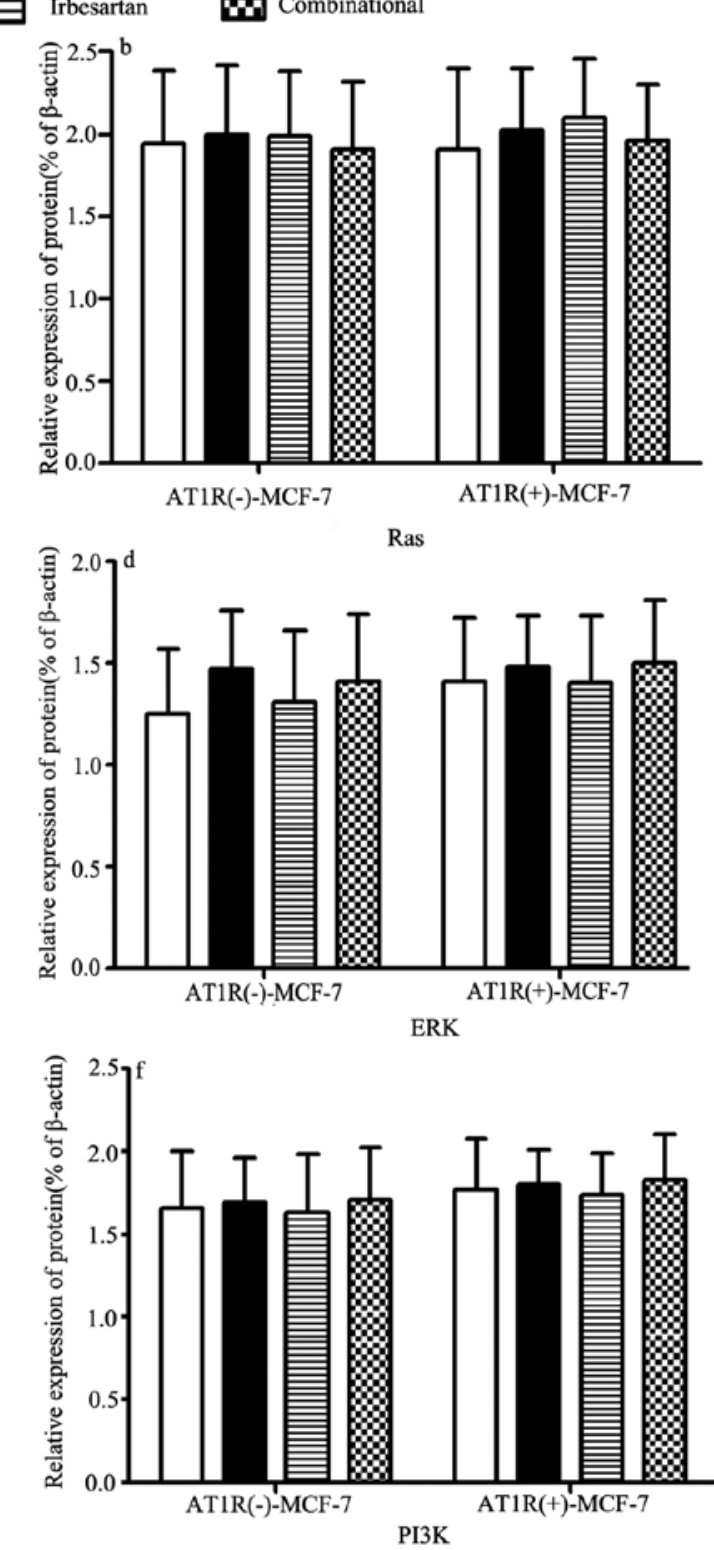

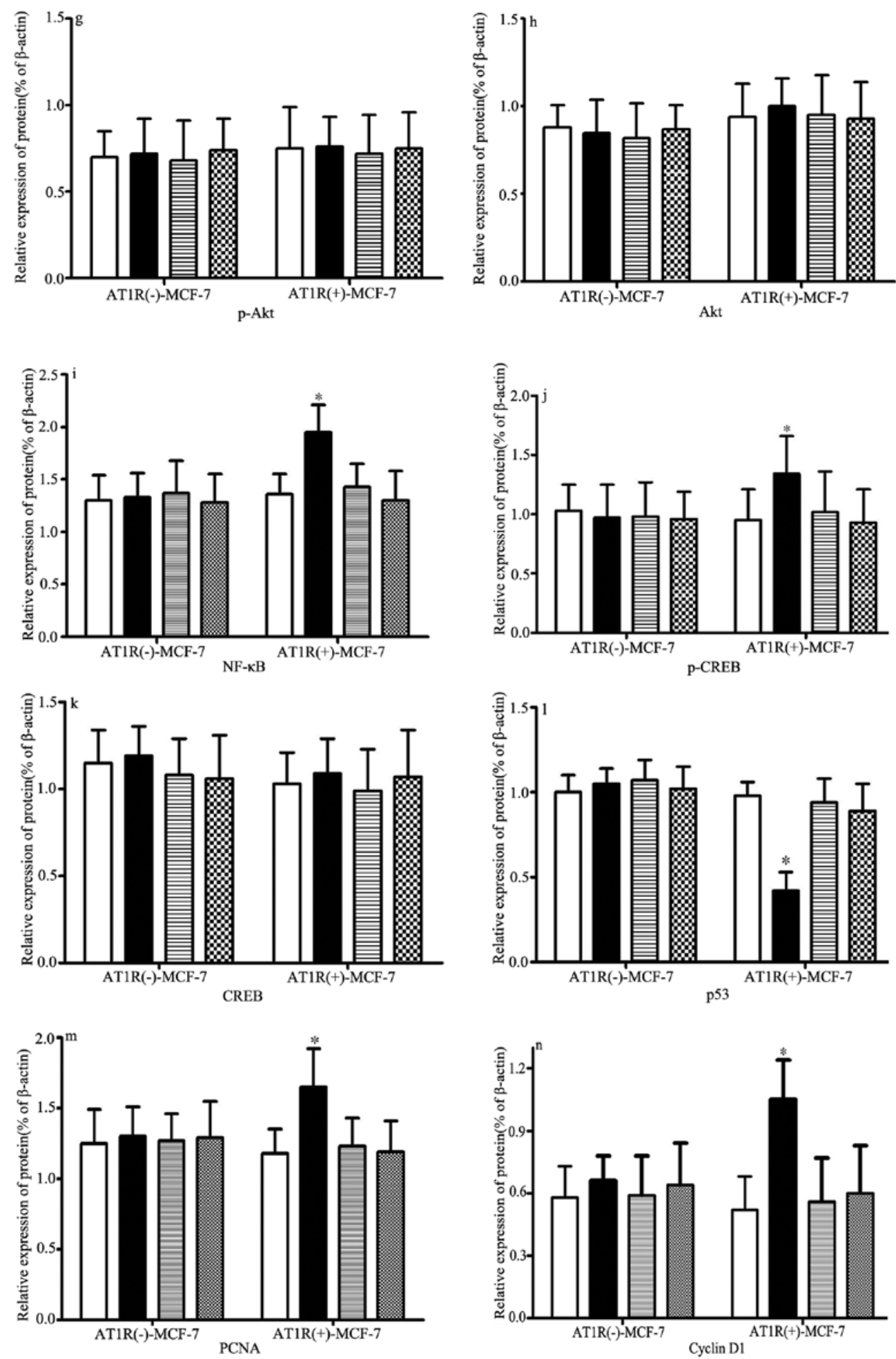

Figure 6. Western blot analysis of downstream effectors of AT1R signaling. (A) The protein levels of p-Ras, Ras, p-Erk, Erk, p-PI3K, PI3K, p-Akt, Akt, NF-kB-P65, p-CREB, CREB, p53, PCNA, cyclin D1 were detected by western blot analysis. Two cell lines were untreated (a and e) or treated for $24 \mathrm{~h}$ with $100 \mathrm{nM}$ Ang II (b and f), $10 \mu \mathrm{M}$ irbesartan (c and g), or $10 \mu \mathrm{M}$ irbesartan added 30 min before $100 \mathrm{nM}$ Ang II treatment (d and h) for $24 \mathrm{~h}$. (B) Bar graph quantification of the results from A.

confirmed that these cells had a marked reduction in protein expression. Using the MCF-7 wild-type and shRNA cell lines, we found that the effects of Ang II were AT1R dependent, and that AT1R or irbesartan alone did not have any effect on cell proliferation or cell cycle progression. We showed that Ang II promoted proliferation, decreased the percentage of cells in G0-G1 phase, and increased the percentage of cells in S phase in the AT1R(+)-MCF-7 cells, but had no effect on AT1R (-)-MCF-7 cells. In other words, the observed Ang II effects were dependent on AT1R. In addition, irbesartan, which is a specific AT1R antagonist, suppressed the effect of Ang II on proliferation and the cell cycle in AT1R(+)-MCF-7 cells, but 
A

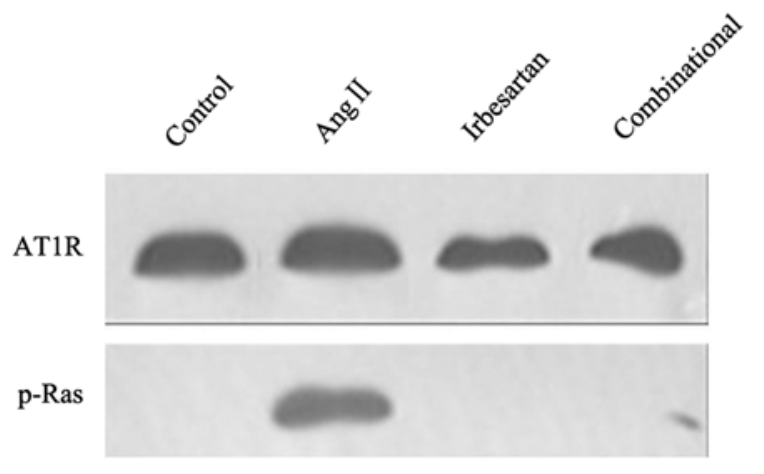

B

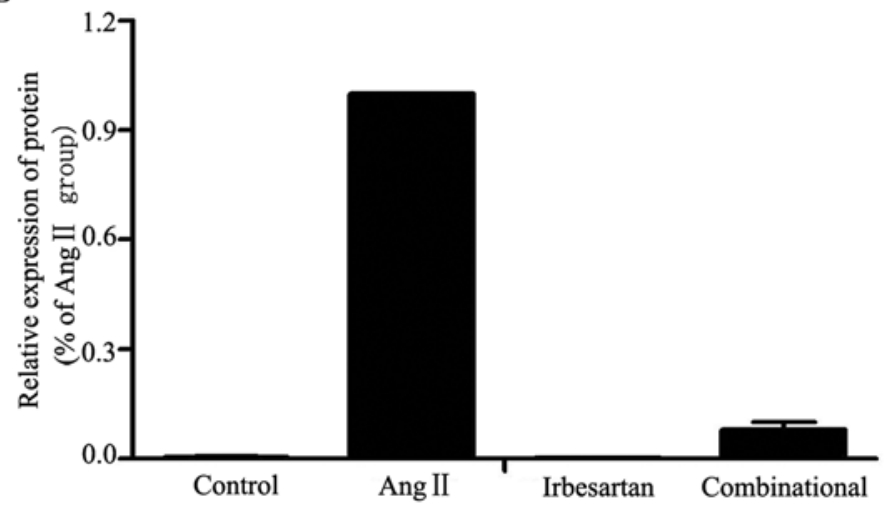

Figure 7. Co-immunoprecipitation of AT1R and p-Ras. (A) Western blot analysis of the co-immunoprecipitation of AT1R and p-Ras. AT1R(+)-MCF-7 cells were not treated (control group) or treated for $24 \mathrm{~h}$ with $100 \mathrm{nM}$ Ang II (Ang II group), $10 \mu \mathrm{M}$ irbesartan (irbesartan group), or $10 \mu \mathrm{M}$ irbesartan added $30 \mathrm{~min}$ before $100 \mathrm{nM}$ Ang II treatment (combinational group). (B) Bar graph representation of the results from A. The expression of p-Ras was significant in Ang II group, compared to other groups $(\mathrm{P}<0.05)$. However, there were no differences of $\mathrm{p}$-Ras expression in irbesartan group, combinational group and control group $(\mathrm{P}>0.05)$.

did not have any effect on AT1R(-)-MCF-7 cells. Therefore, the expression of AT1R is necessary for the Ang II effects on MCF-7 cells. In addition, we found that irbesartan antagonism of AT1R and Ang II effects on these cells did not occur through an apoptotic mechanism.

Previous research has shown that Ang II can activate the Ras-Raf-MAPK pathway to stimulate cell proliferation through AT1R $(20,21,32)$. Our western blot analysis and immunoprecipitation results showed that Ang II can indirectly activate RAS through AT1R activation. Without AT1R expression, Ang II does not activate RAS. Therefore, the positive expression of AT1R in MCF-7 cells plays an important role in the activation of RAS, which can be activated by Ang II. Our study also showed that the activation of RAS through Ang II-mediated activation of AT1R can lead to the downstream activation of the Ras-Raf-MAPK pathway and subsequent ERK phosphorylation. Phosphorylated ERK can then activate transcription factors such as NF- $\kappa$ B and CREB, which are often overexpressed or overactivated in tumors and regulate the expression of downstream genes to promote cell proliferation $(20,33)$. We found that by suppressing AT1R activation with irbesartan, the Ang II-mediated activation of RAS, ERK, NF- $\kappa \mathrm{B}$ and CREB were also suppressed. In addition, our study showed that Ang II activation of AT1R did not induce PI3K or Akt activation. Therefore, the promotion of MCF-7 proliferation by Ang II does not occur through the PI3K/Akt pathway.

We also found that Ang II-mediated activation of AT1R led to a decrease in $\mathrm{p} 53$, which is often downregulated or mutated in most cancers (34), and caused an increase in PCNA and cyclin D1 proteins, which have been found to be upregulated in tumors (35-37). Therefore, our results indicate that Ang II-mediated AT1R activation induces the upregulation of several genes in MCF-7 cells that are known to be involved in cell proliferation and tumor progression. Moreover, this activated pathway also induced a decrease in the tumor suppressor $\mathrm{p53}$, which also promotes uncontrolled cell growth by removing a key cell cycle checkpoint.
In summary, our study demonstrated that Ang II-mediated activation of AT1R can promote cell proliferation and facilitate the G1/S phase transition in a breast cancer cell line, possibly through the activation of the Ras-Raf-MAPK pathway, which leads to the activation of transcription factors $N F-\kappa B$ and CREB. In addition, we found that Ang II treatment caused a decrease in p53, and an increase in PCNA and cyclin D1 expression. Treatment with ARBs, in particular irbesartan, specifically blocked AT1R activation and suppressed the proliferation and cell cycle effects of Ang II on MCF-7 cells. We found that the expression of AT1R was necessary for the observed effects of Ang II on MCF-7 cells. Ang II is constantly secreted in the human body and can persistently stimulate the proliferation of breast cancer cells. Therefore, the use of ARBs to block Ang II signaling may be a new strategy for the prevention and treatment of breast cancer. These findings could be useful in the development of novel preventive and therapeutic methods against breast cancer.

\section{Acknowledgements}

The authors acknowledge Dr Lin Yang of the vascular surgery department and master Zhi-Wei Guo, Chong-Wen Xu and Shuo Li of the Institution of Oncology. The authors also acknowledge the staff of the Key Laboratory of Environment and Genes Related to Disease, Ministry of Education and, Xi'an Jiaotong University for their technical assistance. We thank Medjaden Bioscience Limited for assisting in the preparation of this manuscript.

\section{References}

1. Courneya KS, Mackey JR and McKenzie DC: Exercise for breast cancer survivors: research evidence and clinical guidelines. Phys Sports Med 30: 33-42, 2002

2. Lever AF, Hole DJ, Gillis CR, et al: Do inhibitors of angiotensinI-converting enzyme protect against risk of cancer? Lancet 352 : 179-184, 1998.

3. Gallinat S, Busche S, Raizada MK and Sumners C: The angiotensin II type 2 receptor: an enigma with multiple variations. Am J Physiol Endocrinol Metab 278: E357-E374, 2000. 
4. Ino K, Shibata K, Kajiyama H, Nawa A, Nomura S and Kikkawa F: Manipulating the angiotensin system: new approaches to the treatment of solid tumors. Expert Opin Biol Ther 6: 243-255, 2006.

5. Kikkawa F, Mizuno M, Shibata K, et al: Activation of invasiveness of cervical carcinoma cells by angiotensin II. Am J Obstet Gynecol 190: 1258-1263, 2004.

6. Suganuma T, Ino K, Shibata K, et al: Functional expression of the angiotensin II type 1 receptor in human ovarian carcinoma cells and its blockade therapy resulting in suppression of tumor invasion, angiogenesis, and peritoneal dissemination. Clin Cancer Res 11: 2686-2694, 2005.

7. Juillerat-Jeanneret L, Celerier J, Chapuis Bernasconi C, et al: Renin and angiotensinogen expression and functions in growth and apoptosis of human glioblastoma. Br J Cancer 90: 1059-1068, 2004.

8. Egami K, Murohara T, Shimada T, et al: Role of host angiotensin II type 1 receptor in tumor angiogenesis and growth. J Clin Invest 112: 67-75, 2003

9. Molteni A, Ward WF, Ts'ao CH, et al: Cytostatic properties of some angiotensin I converting enzyme inhibitors and of angiotensin II type 1 receptor antagonists. Curr Pharm Des 9: 751-761, PMID: 2003

10. Fujita M, Hayashi I, Yamashina S, Itoman M and Majima M: Blockade of angiotensin AT1R a receptor signaling reduces tumor growth, angiogenesis, and metastasis. Biochem Biophys Res Commun 294: 441-447, 2002.

11. Noguchi R, Yoshiji H, Kuriyama S, et al: Combination of interferon-beta and the angiotensin-converting enzyme inhibitor, perindopril, attenuates murine hepatocellular carcinoma development and angiogenesis. Clin Cancer Res 9: 6038-6045, 2003.

12. Yasumaru M, Tsuji S, Tsujii M, et al: Inhibition of angiotensin II activity enhanced the antitumor effect of cyclooxygenase-2 inhibitors via insulin-like growth factor I receptor pathway. Cancer Res 63: 6726-6734, 2003.

13. Ohashi $\mathrm{H}$, Takagi $\mathrm{H}$, Oh H, et al: Phosphatidylinositol 3- kinase/ Akt regulates angiotensin II-induced inhibition of apoptosis in microvascular endothelial cells by governing survivin expression and suppression of caspase-3 activity. Circ Res 94: 785-793, 2004.

14. Watanabe Y, Shibata K, Kikkawa F, et al: Adipocyte derived leucine aminopeptidase suppresses angiogenesis in human endometrial carcinoma via rennin-angiotensin system. Clin Cancer Res 9: 6497-6503, 2003.

15. Ino K, Uehara C, Kikkawa F, et al: Enhancement of aminopeptidase A expression during angiotensin II-induced choriocarcinoma cell proliferation through AT1R receptor involving protein kinase $\mathrm{C}$ and mitogen-activated protein kinase-dependent signaling pathway. J Clin Endocrinol Metab 88: 3973-3982, 2003

16. Lam KY and Leung PS: Regulation and expression of a reninangiotensin system in human pancreas and pancreatic endocrine tumours. Eur J Endocrinol 146: 567-572, 2002.

17. Kucerová D, Zelezná B, Sloncová E and Sovová V: Angiotensin II receptors on colorectal carcinoma cells. Int J Mol Med 2 : 593-595, 1998.

18. Greco S, Muscella A, Elia MG, et al: Angiotensin II activates extracellular signal regulated kinases via protein kinase $\mathrm{C}$ and epidermal growth factor receptor in breast cancer cells. J Cell Physiol 196: 370-377, 2003

19. Nishizuka Y: The molecular heterogeneity of protein kinase $C$ and its implications for cellular regulation. Nature 334: 661-665, 1988.

20. Steelman LS, Pohnert SC, Shelton JG, Franklin RA, Bertrand FE and McCubrey JA: JAK/STAT Raf/MEK ERK, PI3K/Akt and BCR-ABL in cell cycle progression and leukemogenesis. Leukemia 18: 189-218, 2004.
21. Arrieta O, Guevara P, Escobar E, García-Navarrete R, Pineda B and Sotelo J: Blockage of angiotensin II type I receptor decreases the synthesis of growth factors and induces apoptosis in C6 cultured cells and C6 rat glioma. Br J Cancer 92: 1247-1252, 2005.

22. Ager EI, Neo $J$ and Christophi C: The renin-angiotensin system and malignancy. Carcinogenesis 29: 1675-1684, 2008.

23. Deshayes F and Nahmias C: Angiotensin receptors: a new role in cancer? Trends Endocrinol Metab 16: 293-299, 2005.

24. Uemura H, Ishiguro H, Nakaigawa N, et al: Angiotensin II receptor blocker shows antiproliferative activity in prostate cancer cells: a possibility of tyrosine kinase inhibitor of growth factor. Mol Cancer Ther 2: 1139-1147, 2003.

25. Takeda $\mathrm{H}$ and Kondo S: Differences between squamous cell carcinoma and keratoacanthoma in angiotensin type-1 receptor expression. Am J Pathol 158: 1633-1637, 2001.

26. Kosugi M, Miyajima A, Kikuchi E, Horiguchi Y and Murai M: Angiotensin II type 1 receptor antagonist candesartan as an angiogenic inhibitor in a xenograft model of bladder cancer. Clin Cancer Res 12: 2888-2893, 2006.

27. Fujimoto Y, Sasaki T, Tsuchida A and Chayama K: Angiotensin II type 1 receptor expression in human pancreatic cancer and growth inhibition by angiotensin II type 1 receptor antagonist. FEBS Lett 495: 197-200, 2001.

28. Huang W, Yu LF, Zhong J, et al: Angiotensin II type 1 receptor expression in human gastric cancer and induces MMP2 and MMP9 expression in MKN-28 cells. Dig Dis Sci 53: 163-168, 2008.

29. Miyajima A, Kosaka T, Asano T, Asano T, Seta K, Kawai T and Hayakawa M: Angiotensin II type 1 antagonist prevents pulmonary metastasis of murine renal cancer by inhibiting tumor angiogenesis. Cancer Res 62: 4176-4179, 2002.

30. Zhao Y, Chen X, Cai L, Yang Y, Sui G and Wu J: Angiotensin II suppresses adriamycin-induced apoptosis through activation of phosphatidylinositol 3-kinase/Akt signaling in human breast cancer cells. Acta Biochim Biophys Sin (Shanghai) 40: 304-310, 2008.

31. Muscella A, Greco S, Elia MG, Storelli C and Marsigliante S: Angiotensin II stimulation of $\mathrm{Na}^{+} / \mathrm{K}^{+}$ATPase activity and cell grow th by calcium-independent pathway in MCF-7 breast cancer cells. J Endocrinol 173: 315-323, 2002.

32. Saito Y and Berk BC: Transactivation: a novel signaling pathway from angiotensin II to tyrosine kinase receptors. J Mol Cell Cardiol 33: 3-7, 2001.

33. Weber AJ, Soong G, Bryan R, Saba S and Prince A: Activation of NF- $\mathrm{KB}$ in airway epithelial cells is dependent on CFTR trafficking and Cl-channel function. Am J Physiol Lung Cell Mol Physiol 281: L71-L78, 2001.

34. Vogelstein B, Lane D and Levine AJ: Surfing the p53 network. Nature 408: 307-310, 2000

35. Aaltomaa S, Lipponen P and Syrjanen K: Prognostic value of cell proliferation in breast cancer as determined by proliferating cell nuclear antigen (PCNA) immunostaining. Anticancer Res 12: 1281-1286, 1992

36. Zafonte BT, Hulit J, Amanatullah DF, et al: Cell-cycle dysregulation in breast cancer: breast cancer therapies targeting the cell-cycle. Front Biosci 5: 938-961, 2000.

37. Kenny FS, Hui R, Musgrove EA, et al: Over-expression of cyclin D1 messenger RNA predicts for poor prognosis in estrogen receptor-positive breast cancer. Clin Cancer Res 5: 2069-2076, 1999. 